\title{
Renal cell cancer among African Americans: an epidemiologic review
}

Loren Lipworth ${ }^{1,2^{*}}$, Robert E Tarone ${ }^{1,2}$ and Joseph K McLaughlin ${ }^{1,2}$

\begin{abstract}
Incidence rates for renal cell cancer, which accounts for 85\% of kidney cancers, have been rising more rapidly among blacks than whites, almost entirely accounted for by an excess of localized disease. This excess dates back to the 1970s, despite less access among blacks to imaging procedures in the past. In contrast, mortality rates for this cancer have been virtually identical among blacks and whites since the early 1990s, despite the fact that nephrectomy rates, regardless of stage, are lower among blacks than among whites. These observations suggest that renal cell cancer may be a less aggressive tumor in blacks. We have reviewed the epidemiology of renal cell cancer, with emphasis on factors which may potentially play a role in the observed differences in incidence and mortality patterns of renal cell cancer among blacks and whites. To date, the factors most consistently, albeit modestly, associated with increased renal cell cancer risk in epidemiologic studies among whites - obesity, hypertension, cigarette smoking - likely account for less than half of these cancers, and there is virtually no epidemiologic evidence in the literature pertaining to their association with renal cell cancer among blacks. There is a long overdue need for detailed etiologic cohort and case-control studies of renal cell cancer among blacks, as they now represent the population at highest risk in the United States. In particular, investigation of the influence on renal cell cancer development of hypertension and chronic kidney disease, both of which occur substantially more frequently among blacks, is warranted, as well as investigations into the biology and natural history of this cancer among blacks.
\end{abstract}

\section{Background}

An estimated 58,240 new cases of kidney cancer and 13,040 deaths are expected in the United States in 2010, accounting for approximately $4 \%$ of all new primary cancer cases diagnosed [1]. Approximately $85 \%$ of kidney cancers are renal parenchyma (renal cell) cancers, while the remainder are mainly urothelial cancers of the renal pelvis [1]. Both renal cell and renal pelvis cancers are about twice as common among men as among women $[1,2]$, with the mean age at diagnosis in the early 60 s for renal cell cancer and in the late 60 s for renal pelvis cancer. Epidemiologic characteristics and risk factors for renal pelvis cancer closely parallel for those for bladder cancer and have been addressed by the authors elsewhere [3].

Over the past several decades, incidence rates for renal cell cancer have been rising steadily each year in the

\footnotetext{
* Correspondence: loren@iei.ws

${ }^{1}$ International Epidemiology Institute, 1455 Research Boulevard, Suite 550, Rockville, MD 20850

Full list of author information is available at the end of the article
}

United States [4]. Improved imaging technology has led to earlier detection and a decrease in the size of diagnosed renal cell tumors over time [5,6], but an increase in the incidence of large and late-stage renal cell cancers has also been observed [4,6,7]. A recent report showed that, while the rate for all cancers combined dropped $1.8 \%$ among men and $0.5 \%$ among women in the United States between 2001 and 2005, kidney cancer incidence is rising $1.7 \%$ per year for males and $2.2 \%$ per year for females [8].

Perhaps the most prominent feature of the descriptive epidemiology of renal cell cancer has been the more rapid increase in incidence among blacks than whites, leading to a shift in excess from among whites to among blacks beginning in the mid-1980s [7] (Figure 1). By 2002-2007, the age-adjusted incidence rates of renal cell cancer among black men, white men, black women, and white women were 20.0, 17.4, 9.6 and 8.8 per 100,000 personyears, respectively [2]. The higher incidence of renal cell cancer among blacks is almost entirely accounted for by an excess of localized disease among patients of all ages
C Biomed Central

(c) 2011 Lipworth et al; licensee BioMed Central Ltd. This is an Open Access article distributed under the terms of the Creative Commons Attribution License (http://creativecommons.org/licenses/by/2.0), which permits unrestricted use, distribution, and reproduction in any medium, provided the original work is properly cited. 


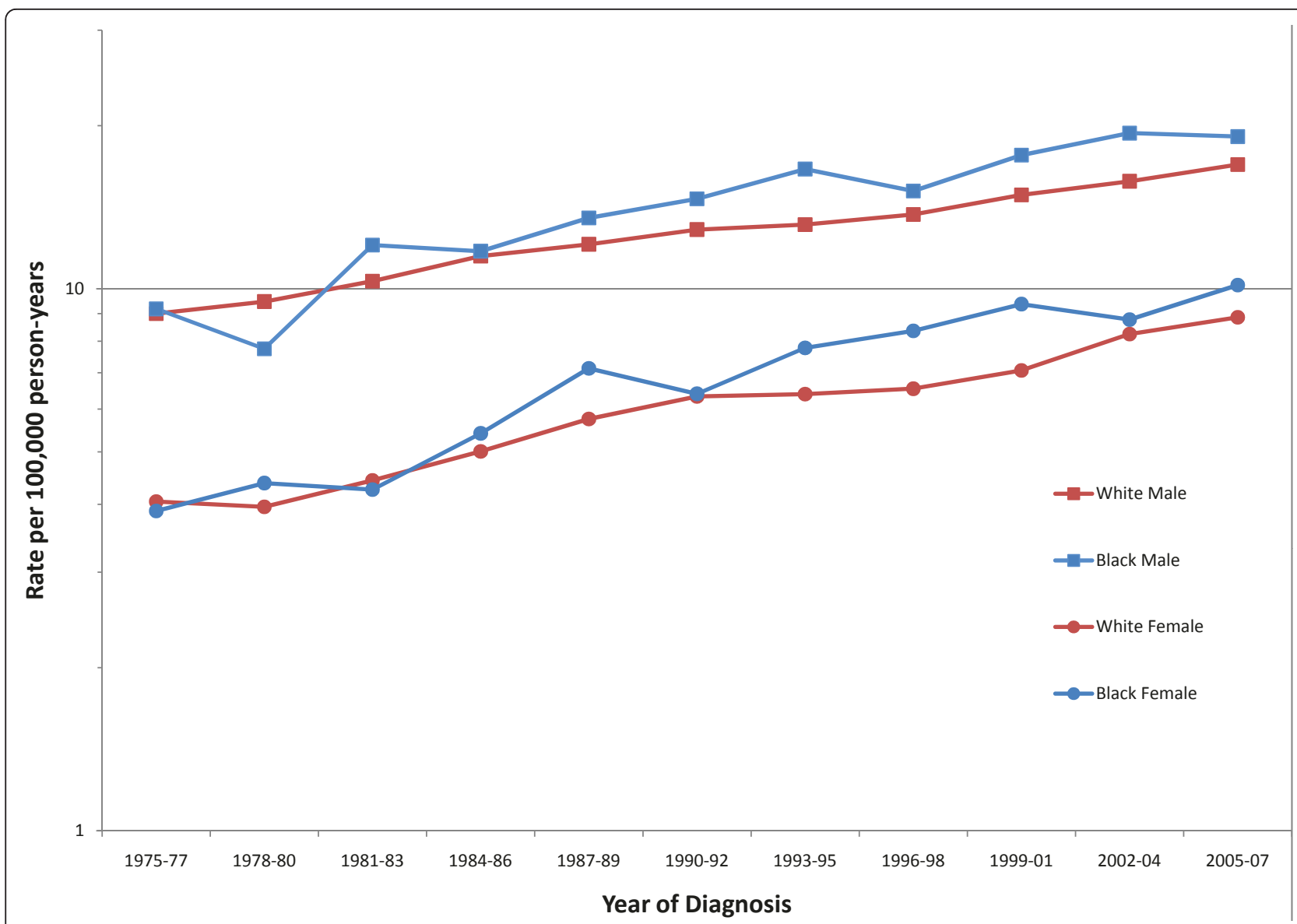

Figure 1 Trends in age-adjusted (2000 United States standard) incidence of renal cell cancer by race and sex, $1974-2007$ (Based on SEER data for nine geographic regions of the United States: Atlanta, Georgia; Connecticut; Detroit, Michigan; Hawaii; lowa; New Mexico; San Francisco/Oakland, California; Seattle/Puget Sound, Washington; and Utah) [2].

and particularly among black men, which dates back to the 1970s [9,10]; for the periods 1973-77, 1978-82 and 1983-87, the incidence rates (per 100,000) for localized renal cell cancer were 3.7, 4.7 and 6.1 for black men, 3.5, 3.9, and 5.0 for white men, 1.8, 2.2 and 2.8 for black women, and 1.7, 1.8 and 2.3 for white women, respectively. Localized renal cell cancer has also been increasing at a significantly faster pace among blacks of all ages than among whites since the 1970s [10].

Early stage renal cell cancer is typically detected incidentally by imaging modalities which, on the basis of socioeconomic factors and accessibility to medical care, are unlikely to be utilized more frequently by blacks than whites $[10,11]$. Viewed historically, access to imaging and other medical technologies was not as available to blacks as it was to whites 30 to 40 years ago when the accelerated increase in the incidence of localized disease began among blacks. It is possible that the diagnostic work-up for co-morbidities more common among blacks may yield incidental findings of localized renal cell tumors. Presently, the higher prevalence of advanced chronic kidney disease among blacks [12] may result in increased renal surveillance with a concomitant increased detection of early renal tumors; but the most common co-morbidities among blacks, hypertension and diabetes, are not generally associated with increased imaging. Thus, the observed differences between blacks and whites in early stage renal cell tumor distribution dating back to the 1970s is unlikely to be a result of long-term greater access to and utilization of imaging technologies by blacks.

In contrast to these incidence trends, United States kidney cancer mortality rates, which include renal pelvis cancer but primarily reflect patterns related to renal cell cancer, have been virtually identical among blacks and whites for both men and women since the early 1990s (Figure 2). This equivalence in mortality despite higher incidence does not appear to be a result of higher rates of nephrectomies among blacks [9]; rates of nephrectomy are in fact lower among blacks than among whites, while cause-specific survival is comparable or higher among blacks. 


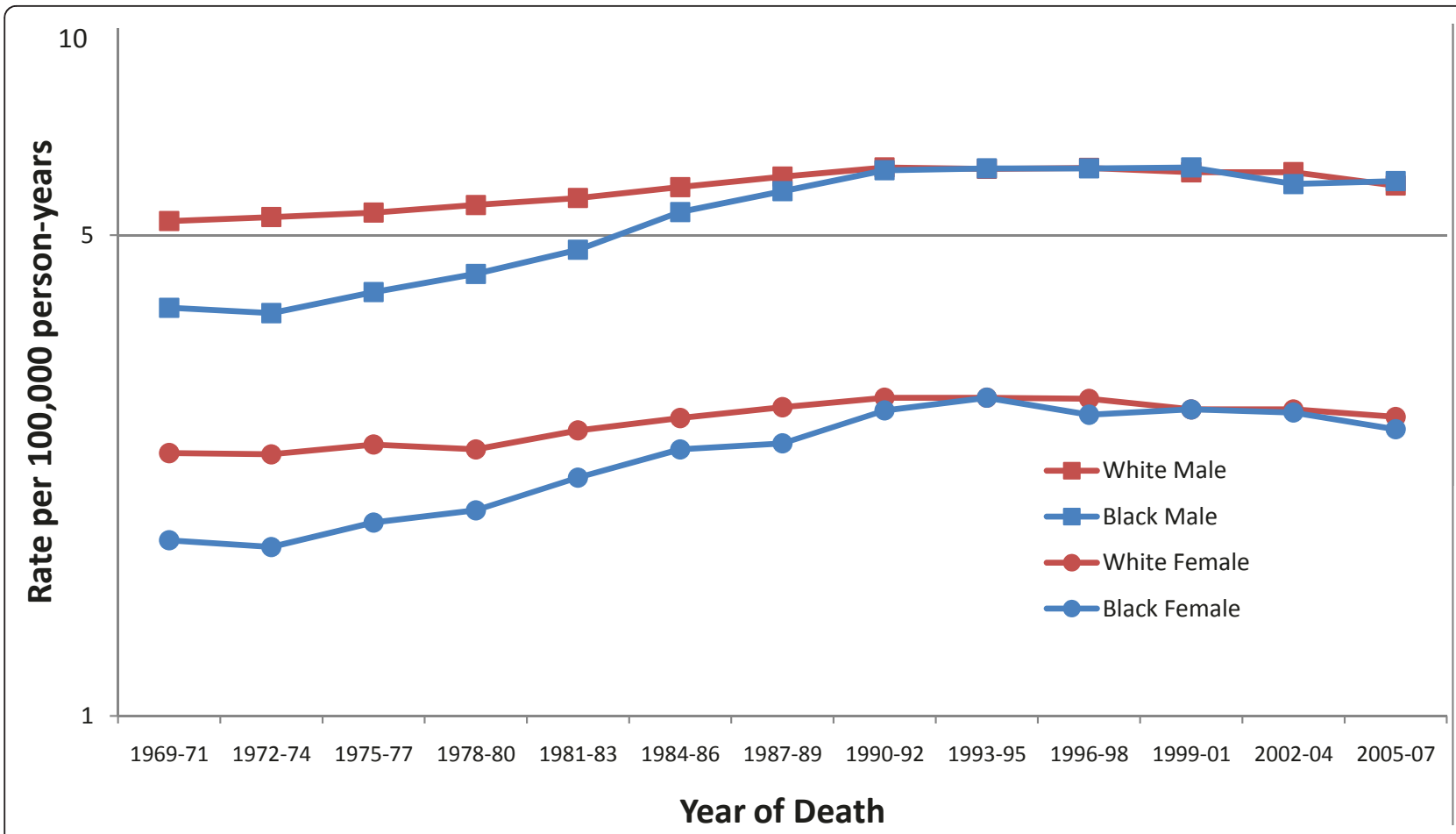

Figure 2 Trends in age-adjusted (2000 United States standard) mortality from kidney cancer by race and sex, 1971-2007 (Based on National Center for Health Statistics data for the entire United States) [2].

These puzzling incidence and mortality trends suggest that the biology of renal cell cancer may differ between blacks and whites. In particular, renal cell cancer may be a less aggressive tumor among blacks [9], as suggested by the favorable stage distribution among blacks and their higher survival, particularly for distant and unstaged cancer. Zini et al. [13] have also reported similar survival despite lower nephrectomy rates among blacks, although others have reported lower survival rates among blacks compared with whites with renal cell cancer $[14,15]$.

\section{Methods}

We have conducted a review of epidemiologic studies of risk factors for renal cell cancer, identified through a PubMed search of the literature. For the purposes of this review, all papers published through 2010 were initially identified by use of either the term "renal cancer" or the term "kidney cancer" together with the term "risk factor" or "epidemiology." Moreover, all review papers addressing risk factors for kidney cancer in general or renal cell cancer in particular were identified, and references were examined to supplement, if necessary, papers identified through the initial search.

A qualitative evaluation and summary of the results of individual studies is presented; rather than citing every paper we have identified, we have chosen to emphasize those results that reflect consistency in the literature and, more importantly, that may potentially play a role in the observed differences in incidence and mortality patterns of renal cell cancer among blacks and whites. No consistent association has been demonstrated between renal cell cancer and social class variables such as education or income. Despite considerable racial differences in the descriptive epidemiology of this malignancy, there have been virtually no etiologic epidemiologic studies presenting results for lifestyle and other risk factors for renal cell cancer separately among blacks, and even the small number of multiethnic studies conducted to date have generally not presented results separately for blacks and whites [16-20], often because of small numbers of blacks in the study population.

\section{Results and Discussion}

\section{Genetic susceptibility}

Renal cell cancer occurs in both hereditary and sporadic forms. Hereditary renal cell cancer tends to occur earlier in life than sporadic forms of the disease, and often involves bilateral, multifocal tumors [21]. Having a first degree relative with kidney cancer has been associated with a 2- to 5-fold increased risk [22]. A recent metaanalysis suggested that the observed risk is higher when the affected relative is a sibling rather than a parent, 
supporting the role of recessive, low-penetrance genes in familial renal cell cancer [22,23]. In a case-control study that evaluated whites and blacks separately and relied on self-reported family history of kidney cancer, the relative risk for renal cell cancer associated with a family history of kidney cancer was higher, although not statistically significantly so, among blacks than among whites [24]; for any first-degree relative with kidney cancer, the relative risk for renal cell cancer was 3.96 (95\% CI 1.4510.84) among blacks and 1.98 (95\% CI 0.99-4.03) among whites.

Although fewer than $5 \%$ of renal cell cancers are explained by inherited predisposition [21,25], no other cancer has as many different types of genetic predisposition as renal cell cancer [26]. Renal medullary cancer is a rare, usually fatal primary kidney tumor that afflicts almost exclusively young blacks with sickle cell trait or disease [27]. The tumor, which displays unique clinical and pathological characteristics, originates from the epithelium of renal collecting ducts, and is almost always metastatic at the time of diagnosis, with death usually occurring within a few months of diagnosis. This highly aggressive tumor was first described in 1995 [28], and approximately 120 cases have been reported to date, virtually all among patients aged less than 40 years [29].

Other rare genetic forms of renal cell cancer are von Hippel-Lindau (VHL) disease (predisposing to clear cell cancer), hereditary papillary renal cell carcinoma (HPRC), hereditary leiomyomatosis renal cell cancer (papillary), Birt-Hogg-Dubé syndrome (mainly chromophobe and oncocytoma), chromosome 3 translocationassociated (clear cell), tuberous sclerosis (clear cell), mutated succinate dehydrogenase genes, and Cowden syndrome $[21,25,30]$. Genes have been identified related to these inherited forms of renal cell cancer: the tumor suppressor $V H L$ gene located on the distal region of chromosome $3 \mathrm{p}$ [31], the EPAS-1 gene encoding the HIF- $2 \alpha$ transcription factor that is critical in kidney carcinogenesis for VHL-deficient RCC [32], six different rare germline translocations affecting chromosome 3 in a small number of families with familial clear cell renal cancer [33-35], the $M E T$ gene for hereditary papillary carcinoma, the FLCN gene for Birt-Hogg-Dubé syndrome, the $F H$ gene for hereditary leiomyomatosis renal cell cancer, three succinate dehydrogenase genes including $S D H B$ [36], and the tumor suppressor phosphatase and tensin homolog (PTEN) and KILLIN genes in Cowden syndrome [37]. All of the identified genes are involved in pathways that respond to metabolic stress or nutrient stimulation [36]. Aside from the sickle cell trait, none of the inherited syndromes associated with increased risk of kidney cancer has been reported to have a higher prevalence in blacks.

\section{Chronic kidney disease}

It is well-established that patients on renal replacement therapy for end stage chronic kidney disease are at increased risk for many cancers [38]. In particular, several large studies conducted in North America, Europe, or Australia and New Zealand have reported substantially elevated relative risks for renal cell cancer among patients on dialysis or renal transplantation therapy for end-stage kidney disease, independent of underlying primary renal disease, with relative risks ranging from 3.3 up to almost 15 [39-44]. The risk for renal cell cancer rises with duration of dialysis treatment [44]. Acquired renal cystic disease of the native kidneys, which occurs among dialysis patients independent of age or primary renal disease and whose prevalence also increases with duration of dialysis, is believed to account for the excess of renal cell carcinoma among patients on dialysis $[44,45]$. The increased cancer risk among transplant recipients is likely due, at least in part, to the use of immune-suppressing medications [38]. Evidence for an association between early stage chronic kidney disease and renal cell cancer risk is more limited [42,46].

Rates of end stage renal disease, in particular hypertension- and diabetes- related end stage renal disease, are consistently reported to be at least four-fold higher among blacks than among whites [47-49]. The rate of hypertension-related end stage renal disease is 20 times higher among 20 to 44 year old black males compared with their white counterparts [48]. In contrast, rates of earlier stage chronic kidney disease are similar or increased among whites compared with blacks [12,50,51]. Between 1999 and 2004, the prevalence of all stages of chronic kidney disease combined, defined by a combination of glomerular filtration rate (GFR) $<60 \mathrm{ml} / \mathrm{min} / 1.73$ $\mathrm{m}^{2}$ and high proteinuria, was reported to be $16.1 \%$ among whites and $19.9 \%$ among blacks [52]. Detailed analyses based on GFR measurements have demonstrated a white excess for mild chronic kidney disease giving way to a black excess for moderate to severe chronic kidney disease [52,53]. For example, in the Reasons for Geographic And Racial Differences in Stroke (REGARDS) cohort study, the black:white odds ratio for impaired kidney function was 0.74 (95\% CI 0.66-0.84) among individuals with a GFR between 50 and $59 \mathrm{ml} / \mathrm{min} / 1.73 \mathrm{~m}^{2}$, increasing to 2.96 (95\% CI 1.72-5.11) among those with a GFR between 10 and $19 \mathrm{ml} / \mathrm{min} / 1.73 \mathrm{~m}^{2}$ [53]. It has also been suggested that a lower level of blood pressure may be necessary to slow the decline in renal function among blacks with chronic kidney disease and hypertension compared with whites $[54,55]$, but racial differences in the susceptibility to renal damage from elevated blood pressure have been reported to persist even after adjustment for differences between blacks and whites in hypertension and hypertension-control [56]. 
A recent study [57] showed that, among blacks, focal segmental glomerulosclerosis and hypertension-attributed end-stage kidney disease are strongly associated with variants in the APOL1 gene on chromosome 22, supporting a genetic basis for predisposition to kidney disease in blacks. The APOL1 risk alleles for renal disease occur in more than $30 \%$ of African-American chromosomes but appear to be absent in whites [57], and it is possible that a similar genetic marker associated with renal cell cancer may exist among blacks.

\section{Obesity}

Regardless of study design, renal cell cancer is consistently associated with obesity. The association of renal cell carcinoma with obesity has been reported in virtually all epidemiologic studies, including many large prospective studies conducted in various populations, and most studies have observed an effect of elevated BMI among both men and women. Only one large cohort study of 3,668,486 white and 832,214 black male US veterans has specifically evaluated obesity-related renal cell cancer risk separately among blacks, but it used a hospital diagnosis of obesity rather than BMI as the measure of exposure [58]. The relative risks for renal cell cancer associated with clinical obesity were 1.74 (95\% CI 1.58-1.90) among white men and 1.38 (95\% CI 1.09-1.74) among black men. Risk for renal cell cancer was significantly elevated among white men with or without hypertension, while among black men risk of renal cell cancer was not elevated among those without hypertension [58]. In a large, Swedish population-based study that used measurements of height and weight rather than questionnaire-derived data, the relative risks for renal cell cancer associated with being overweight (BMI 25.0-29.9) or obese (BMI > 30) were 1.28 and 1.82 , respectively [59].

Recent quantitative summary analyses of the epidemiologic evidence reported that associations with increased BMI were slightly stronger in women than in men [60-62]; Renehan et al. presented summary risk ratios of 1.24 (95\% CI 1.15-1.34) among men and 1.34 (95\% CI 1.25-1.43) among women per $5 \mathrm{~kg} / \mathrm{m}^{2}$ increase in BMI [62], while pooled relative risks from cohort studies were 1.06 among women and 1.05 among men per unit increase in BMI [60,61].

The rising incidence of renal cell cancer is likely to be accounted for in part by the increasing prevalence of obesity $[63,64]$, although increases in obesity prevalence observed since the 1980s may not be continuing at the same rate in recent years, particularly among white men [62]. In 2007-2008 in the United States, the prevalence of obesity (BMI $\geq 30$ ) and of obesity and overweight combined $(\mathrm{BMI} \geq 25)$ were $33.8 \%$ and $68 \%$, respectively [62]. The prevalence of obesity in the United States is up to $50 \%$ higher among blacks when compared with whites, with the difference more pronounced among women than men $[62,63]$. The proportion of renal cell cancer attributable to being overweight and obese could be as high as $40 \%$ in the United States and Canada [64-66].

Several credible mechanisms have been suggested for the association between obesity and renal cell cancer. Obesity regulates the release of free fatty acids and adipose tissue-derived hormones and cytokines, including leptin and adiponectin [34]. While levels of most cytokines, including leptin, are increased in obese individuals, serum adiponectin levels are inversely correlated with BMI among both blacks and whites [67-69], and appear to be lower in blacks compared with whites [67,69-74]. A few small studies have shown reduced adiponectin levels in patients with renal cell cancer, and an inverse correlation between adiponectin levels and markers of tumor aggressiveness, including tumor size and metastasis [75-77]. Moreover, circulating levels of adiponectin are inversely associated with insulin resistance, and elevated circulating insulin levels and increases in the bioavailability of insulin-like growth factor-I (IGF-I) associated with obesity could in turn lead to increased cell proliferation and the development of renal cell cancer [78-80]. A recent study showed that, while BMI was associated with IGF-1 levels regardless of race, black women had higher mean IGF-1 levels compared with white women adjusted for BMI. Lipid peroxidation of proximal renal tubules, which is increased among obese subjects, has also been hypothesized to play a role in the association of obesity with renal cell cancer through the formation of DNA adducts [81].

\section{Hypertension}

While it is difficult to separate the effects of hypertension or its treatment on renal cell cancer risk, as they are highly correlated variables, the collective epidemiologic evidence to date suggests that it is hypertension itself that plays a role in the etiology of this tumor. There appears to be no excess risk for renal cell cancer associated with use of any type of class of antihypertensive medications or with diuretic use, after adjustment for high blood pressure [82-86]. Most studies have reported relative risks for renal cell cancer associated with either recorded blood pressure or reported hypertension ranging between 1.2 and 2 or greater, and several cohort studies have demonstrated an increased risk even after exclusion of the first few years of follow-up, when early stage, prediagnostic renal tumors may themselves lead to elevated blood pressure $[20,82-84,87,88]$.

Trends of increasing renal cell cancer incidence may be associated with the increasing prevalence of hypertension in the United States [89-91], particularly among 
blacks. While awareness and treatment of hypertension has improved among blacks over time, a substantially higher prevalence of hypertension among blacks compared with whites persists, as does the large difference between blacks and whites in the proportion of patients with hypertension who are receiving treatment $[91,92]$. The diagnostic work-up for hypertension, while more common among blacks, is not generally associated with increased imaging, so hypertension is unlikely to account for the more common occurrence of incidental localized renal cell tumors among blacks compared with whites. In fact, detection bias due to incidental diagnosis during work-ups for hypertension was not supported in a study which directly evaluated that hypothesis [93]. Although the effect of hypertension on renal cell cancer is believed to be independent of obesity, adiponectin levels are lower among blacks than among whites, and low adiponectin levels have been linked in a few studies to hypertension as well as obesity. Moreover, despite the linear relationship between increased body weight and increased blood pressure in whites, it has been suggested that blacks have higher blood pressures at lower weights compared with whites [94].

Several biologic mechanisms for the association between high blood pressure and renal cell cancer risk have been proposed, including hypertension-induced renal injury or metabolic or functional changes within the renal tubule induced by hypertension increasing susceptibility to carcinogens. It has also been speculated that elevated levels of insulin-like growth factor-I (IGFI) or lipid peroxidation associated with hypertension, as well as up-regulation of hypoxia-inducible factors, could contribute to the development of renal cell cancer.

\section{Cigarette smoking}

Cigarette smoking is a recognized though moderate cause of renal cell cancer [95]. A meta-analysis [96] of data from 19 case-control studies $(8,032$ cases and 13,800 controls) and 5 cohort studies $(1,457,754$ participants with 1,326 renal cell cancer cases) reported statistically significant relative risks of 1.5 and 1.2 for male and female smokers, respectively. There was a strong dose-dependent increase in risk, up to 2- and 1.6-fold among heavy ( 21 or more cigarettes per day) men and women smokers, respectively. There was a significant decline in risk in both sexes with years of cessation, with a 15 to $30 \%$ reduction in risk 10 to 15 years after quitting [96]. Approximately 20 to $30 \%$ of renal cell cancers among men and 10 to $20 \%$ among women are estimated to be attributable to cigarette smoking $[89,97,98]$. According to the 1998 Surgeon General's report on tobacco use, the prevalence of smoking declined among African Americans between 1978 and 1995 , from $37.3 \%$ to $26.5 \%$ overall, and while blacks have higher rates of smoking they are less likely than whites to be heavy smokers and smoke fewer cigarettes per day, so this causal factor is an unlikely explanation for the excess incidence of renal cell cancer among blacks [99].

\section{Statins}

Statins are widely used drugs for the treatment of lipid disorders, particularly hypercholesterolemia. Antitumorigenic properties of statins have been documented, including their inhibition of proliferation and promotion of apoptosis, but their potential effectiveness for the primary prevention of cancer has not been conclusively demonstrated. Despite observed differences between blacks and whites in both the prevalence of hypercholesterolemia and its treatment with statins, both lower among blacks than whites $[100,101]$, to our knowledge no study has evaluated the association between statin use and renal cell cancer among blacks.

\section{Other lifestyle factors}

Several other factors have been extensively evaluated in epidemiologic studies of renal cell cancer. However, credible or consistent associations of these factors with renal cell cancer have not been reported, and they do not play an obvious role in explaining the unusual patterns of renal cell cancer incidence and mortality among blacks and whites. The collective epidemiologic evidence related to these characteristics and risk factors has been addressed by the authors in detail elsewhere [102,103] and, therefore, will be mentioned here only in brief.

\section{Analgesics}

Historically, the causal connection of heavy use and abuse of phenacetin-containing analgesics and transitional cell cancers of the renal pelvis has long been recognized [3]. Phenacetin's effect on adenocarcinomas of the renal parenchyma, however, is inconclusive, and it is now impossible to assess because phenacetin-containing analgesics have been off the market for up to 30 years in most countries and reliable recall of past intake is no longer achievable. Neither acetaminophen, the major metabolite of phenacetin, nor aspirin has been credibly associated with an increase in renal cell cancer risk. To date, there is no epidemiologic investigation of analgesic use and renal cell cancer among blacks.

\section{Diet}

Although originally thought almost 40 years ago to play a key role in renal cell cancer etiology, dietary factors have not fulfilled their early promise, as renal cell cancer has not been convincingly linked to any specific dietary factor. To our knowledge, there has been no etiologic study of renal cell cancer and diet to publish results specifically among blacks. A protective effect for overall fruit and vegetable consumption has been generally 
accepted, but two recent large prospective studies, one based on 375,851 participants in the European Prospective Investigation into Cancer And Nutrition (EPIC) [104] and the other based on 120,852 men and women in the Netherlands cohort study on diet and cancer (NLCS) [105], reported no protective effect of vegetable and/or fruit consumption on renal cell cancer. Some epidemiologic studies suggest that elevated protein consumption may be a risk factor for renal cell cancer. There may be some biologic plausibility to a high protein diet affecting risk of renal cell cancer, because animal studies have shown protein intake can induce renal tubular hypertrophy, but the large international renal cell cancer case-control study failed to provide clear support for this hypothesis [106], as did a large, pooled analysis of 13 cohort studies [107].

\section{Alcohol consumption}

Early ecologic studies consistently suggested a positive correlation between kidney cancer and per capita consumption of alcohol, but these ecologic findings were not confirmed by numerous analytic epidemiologic studies of renal cell cancer conducted during the ensuing two decades $[100,101]$. After adjustment for the confounding effect of cigarette use, virtually all studies, including cohort studies of alcoholics and brewery workers, showed no association between alcohol consumption and renal cell cancer.

By contrast, a post hoc hypothesis has recently appeared in the literature that moderate levels of alcohol consumption may be protective for renal cell cancer. The findings of recent individual studies show considerable heterogeneity and inconsistency with respect to the categories of alcohol consumption, the amount of alcohol intake reportedly associated with decreased renal cell cancer risk, and differential observations between men and women. A pooled analysis of data from 12 prospective studies of renal cell cancer was recently published, based on results of five published studies as well as numerous others which had not previously published their data related to alcohol consumption [108]. The pooled analysis was based on 1430 incident cases of renal cell cancer (719 men and 711 women), and demonstrated an apparent inverse-response relation at levels of consumption equivalent to less than a drink per day, with no further protective effect at levels of intake above a drink a day. It is difficult to imagine the biologic mechanism that could explain this unusual type of dose-response pattern. Unless of course one invokes a hormesis-like effect of low-dose alcohol on renal cancer risk while other body organs apparently do not enjoy this low-dose anti-carcinogenic effect.

Finally, alcohol itself is a known human carcinogen and heavy alcohol drinking has been conclusively linked to increased risks of numerous types of cancer, including oral, pharyngeal, laryngeal, esophageal, liver and probably breast and colon and rectum [109]. A protective effect of alcohol consumption on renal cell cancer at very low levels of intake has little biologic plausibility or credibility. In addition to the extensive analytic epidemiologic evidence from the past 40 years, the descriptive patterns of renal cell cancer are not consistent with an inverse association with alcohol intake. In particular, the rate of renal cell cancer among men is twice that among women worldwide, whereas men tend to consume alcohol at substantially higher levels than women.

\section{Hormonal and reproductive factors}

Reductions in risk of renal cell cancer have been reported among users of oral contraceptives in some $[110,111]$ but not all studies [112,113], and in the large international case-control study protection was restricted to non-smokers [110]. Hormones have induced renal tumors in laboratory animals; however, with the exception of an almost two-fold increased risk among women with high parity compared with nulliparous women in some studies, after adjustment for obesity $[110,111,114]$, evidence for a role of hormonal or reproductive factors in the etiology of renal cell cancer in humans is not strong or consistent.

\section{Occupation}

As compared with bladder cancer, renal cell cancer has not been convincingly linked to any occupational exposure. However, because of the large number of epidemiologic studies of this cancer, particularly case-control studies, that have been conducted over the last three decades, a number of sporadic associations have been reported between exposures or jobs/industries and renal cell cancer. Most attention has been focused on asbestos, gasoline and, more recently, the solvent trichloroethylene (TCE). Extensive reviews and meta-analyses of occupational cohort studies have failed to confirm suspicions of increased risk of kidney cancer among workers exposed to asbestos or gasoline [115-117].

Three epidemiologic studies conducted in one area of Germany, which were initiated in response to a cluster of renal cell cancer cases observed in a plant, reported strikingly elevated relative risks for renal cell cancer associated with TCE exposure [118-120]. The findings contrast starkly with results from other investigations, and several serious methodological shortcomings of these studies have been noted [121-123] limiting any conclusion that can be drawn. To date, seven occupational cohort studies have evaluated the relationship between TCE exposure and specific types of cancer. The two largest, which both employed sophisticated methods of exposure assessment and internal and external comparisons $[124,125]$, reported no significantly increased risk of renal cell cancer among TCE exposed workers. The most recent cohort study [126], conducted in 
Denmark, evaluated cancer incidence among 40,049 workers with presumed TCE exposure and found a weak association with renal cell cancer among those thought to be heavily exposed to TCE. The weight of the evidence to date, however, does not provide consistent, credible support for the hypothesis that TCE is a cause of renal cell cancer in humans [127]. Whether TCE is a renal carcinogen in humans remains an open question, which will require more and better research.

\section{Conclusions}

To date, the factors most consistently associated with increased renal cell cancer risk in epidemiologic studies obesity, hypertension, cigarette smoking - likely account for less than half of these cancers among whites, and there is scant published evidence pertaining to their association among blacks with renal cell cancer. In light of the enigmatic differences in incidence and mortality trends in renal cell cancer among blacks, there is an urgent need for detailed etiologic cohort and case-control studies of renal cell cancer among blacks, as they now represent the population at highest risk in the United States. In particular, detailed investigations are needed of the influence on renal cell cancer development of hypertension and chronic kidney disease, both of which occur much more commonly among blacks, as well as investigations of genetic markers which may reflect greater susceptibility to renal cell cancer among blacks. Further, detailed studies of the biology and natural history of renal cell cancer among blacks are essential.

\section{Acknowledgements}

Funded in part by The Southern Community Cohort Study (SCCS) grant R01 CA092447 from the National Cancer Institute (NCI).

\section{Author details}

${ }^{1}$ International Epidemiology Institute, 1455 Research Boulevard, Suite 550, Rockville, MD 20850. ²Department of Medicine, Vanderbilt University Medical Center and Vanderbilt-Ingram Cancer Center, Nashville, TN, USA.

\section{Authors' contributions \\ $\mathrm{LL}, \mathrm{RET}$ and JKM all made substantial contributions to conception, analysis and interpretation of published results for this review, and drafting of the manuscript. All authors have given final approval of the version to be published.}

\section{Declaration of competing interests}

The authors declare that they have no competing interests.

Received: 4 October 2010 Accepted: 12 April 2011

Published: 12 April 2011

\section{References}

1. Jemal A, Siegel R, Xu J, Ward E: Cancer statistics, 2010. Ca Cancer J Clin 2010, 60:277-300.

2. National Cancer Institute: DCCPS, Surveillance Research Program, Cancer Statistics Branch. SEER Program 17 Registries Public Use Tapes (1973-2007, varying), November 2008 Submission, Released April 2009.

3. McLaughlin JK, Lipworth L, Tarone RE, Blot WJ: Renal cancer. In Cancer Epidemiology and Prevention.. 3 edition. Edited by: Schottenfeld D, Fraumeni JF Jr. New York: Oxford University Press; 2006:1087-1100.
4. Mathew A, Devesa SS, Fraumeni JF Jr, Chow WH: Global increases in kidney cancer incidence, 1973-1992. Eur J Cancer Prev 2002, 11:171-178.

5. Nguyen MM, Gill IS, Ellison LM: The evolving presentation of renal carcinoma in the United States: trends of the Surveillance, Epidemiology, and End Results Program. J Urol 2006, 176:2397-2400.

6. Hollingsworth JM, Miller DC, Daignault S, Hollenbeck BK: Rising incidence of small renal masses: a need to reassess treatment effect. J Natl Cancer Inst 2006, 98:1331-1334.

7. Kosary CL, McLaughlin JK: Kidney and renal pelvis. In Cancer Statistics Review: 1973-1990. Edited by: Miller BA, Ries LAG, Hankey BE. National Cancer Institute. NIH Pub. No. 93-2789; 1993:XI-X22.

8. Jemal A, Thun MJ, Ries LAG, Howe HL, Weir HK, Center MM, Ward E, Wu XC, Eheman C, Anderson R, Ajani UA, Kohler B, Edwards BK: Annual report to the nation on the status of cancer, 1975-2005, featuring trends in lung cancer, tobacco use, and tobacco control. J Natl Cancer Inst 2008, 100:1672-1694

9. Lipworth L, McLaughlin JK, Tarone RE, Blot WJ: Renal cancer paradox: Higher incidence but not higher mortality among African Americans. Eur $J$ Cancer Prev.

10. Vaishampayan $\mathrm{N}$, Do H, Hussain $M$, Schwartz K: Racial disparity in incidence patterns and outcome of kidney cancer. Urol 2003, 62:1012-1017.

11. Geronimus AT, Bound J, Waidmann TA, Hillemeier MM, Burns PB: Excess mortality among blacks and whites in the United States. N Engl J Med 1996, 335:1552-1558.

12. McClellan W, Warnock DG, McClure L, Campbell RC, Newcome BB, Howard V, Cushman M, Howard G: Racial differences in the prevalence of chronic kidney disease among participants in the Reasons for Geographic and Racial Differences in Stroke (REGARDS) Cohort Study. J Am Soc Nephrol 2006, 17:1710-1715.

13. Zini L, Perrotte P, Capitanio U, Jeldres C, Duclos A, Arjane P, Villers A, Montorsi F, Patard J-J, Karakiewicz PI: Race affects access to nephrectomy but not survival in renal cell carcinoma. BJU Int 2008, 103:889-893.

14. Berndt SI, Carter HB, Schoenberg MP, Newschaffer CJ: Disparities in treatment and outcome for renal cell cancer among older black and white patients. J Clin Oncol 2007, 25:3589-3595.

15. Stafford HS, Saltzstein SL, Shimasaki S, Sanders C, Downs TM, Sadler GR: Racial/ethnic and gender disparities in renal cell carcinoma incidence and survival. J Urol 2008, 179:1704-1708.

16. Miller DC, Ruterbusch J, Colt JS, Davis FG, Linehan WM, Chow WH, Schwartz K: Contemporary clinical epidemiology of renal cell carcinoma: insight from a population based case-control study. J Urol 2010, 184:2254-2258.

17. Theis RP, Dolwick Grieb SM, Burr D, Siddiqui T, Asal NR: Smoking, environmental tobacco smoke, and risk for renal cell cancer: results from a population-based case-control study. BMC Cancer 2008, 8:837.

18. Grieb SM, Theis RP, Burr D, Benardot D, Siddiqui T, Asal NR: Food groups and renal cell carcinoma: results from a case-control study. J Am Diet Assoc 2009, 109:656-667.

19. Asal NR, Theis RP, Dolwick Grieb SM, Burr D, Benardot D, Siddiqui T: Obesity, body composition and risk of renal cell cancer: a populationbased case-control study. Int J Health Sci 2009, 2:167-175.

20. Setiawan WW, Stram DO, Nomura AMY, Kolonel LN, Henderson BE: Risk factors for renal cell cancer: the multiethnic cohort. Am J Epidemiol 2007, 166:932-940

21. Choyke PL, Glenn GM, Walther MM, Zbar B, Linehan WM: Hereditary renal cancers. Radiology 2003, 226:33-46.

22. Clague J, Lin J, Cassidy A, Matin S, Tannir NM, Tamboli P, Wood CG, Wu X Family history and risk of renal cell carcinoma: results from a casecontrol study and systemic meta-analysis. Cancer Epidemiol Biomarkers Prev 2009, 18:801-807.

23. Risch $\mathrm{N}$ : The genetic epidemiology of cancer: interpreting family and twin studies and their implications for molecular genetic approaches. Cancer Epidemiol Biomarkers Prev 2001, 10:733-741.

24. Karami S, Schwartz K, Purdue MP, Davis FG, Ruterbusch JJ, Mumuo SS, Wacholder S, Braubard BI, Colt JS, Chow WH: Family history of cancer and renal cell cancer risk in Caucasians and African Americans. Br J Cancer 2010, 102:1676-1680.

25. Ricketts C, Woodward ER, Killick P, Morris MR, Astuti D, Latif F, Maher ER: Germline SDHB mutations and familial renal cell carcinoma. J Natl Cancer Inst 2008, 100:1260-1262. 
26. Cohen HT, McGovern FJ: Renal cell carcinoma. N Eng J Med 2005, 353:2477-2490

27. Tsaras G, Awusu-Ansah A, Boateng FO, Amoateng-Adjepong Y: Complications associated with sickle cell trait: a brief narrative review. Am J Med 2009, 122:507-512.

28. Davis CJ, Mostofi FK, Sestarhenn IA: Renal medullary carcinoma. The seventh sickle cell nephropathy. Am J Surg Pathol 1995, 19:1-11.

29. Watanabe IC, Billis A, Guimaraes MS, Alvarenga M, de Matos AC, Cardinalli IA, Filippi RZ, de Castro MG, Suzigan S: Renal medullary carcinoma: report of seven cases from Brazil. Mod Pathol 2007, 20:914-920.

30. Riegert-Johnson DL, Gleeson FC, Roberts M, Tholen K, Youngborg L, Bullock M, Boardman LA: Cancer and Lhermitte-Duclos disease are common in Cowden syndrome patients. Hered Cancer Clin Pract 2010, 8:6.

31. Linehan WM, Lerman Ml, Zbar B: Identification of the von Hippel-Lindau (VHL) gene. Its role in renal cancer. JAMA 1995, 273:564-570

32. Purdue MP, Johansson M, Zelenika D, Toro JR, Scelo G, Moore LE, Prokhortchouk E, Wu X, Kiemeney LA, Gaborieau V, Jacobs KB, Chow WH, Zaridze D, Matveev V, Lubinski J, Trubicka J, Szeszenia-Dabrowska N, Lissowska J, Rudnai P, Fabianova E, Bucur A, Bencko V, Foretova L, Janout V, Boffetta P, Colt JS, Davis FG, Schwartz KL, Banks RE, Selby PJ, Harnden P, Berg CD, Hsing AW, Grubb RL, Boeing $H$, Vineis $P$, Clavel-Chapelon F, Palli D, Tumino R, Krogh V, Panico S, Duell EJ, Quirós JR, Sanchez MJ, Navarro C, Ardanaz E, Dorronsoro M, Khaw KT, Allen NE, Bueno-deMesquita HB, Peeters PH, Trichopoulos D, Linseisen J, Ljungberg B, Overvad K, Tjønneland A, Romieu I, Riboli E, Mukeria A, Shangina O, Stevens VL, Thun MJ, Diver WR, Gapstur SM, Pharoah PD, Easton DF, Albanes D, Weinstein SJ, Virtamo J, Vatten L, Hveem K, Njølstad I, Tell GS, Stoltenberg C, Kumar R, Koppova K, Cussenot O, Benhamou S, Oosterwijk E, Vermeulen SH, Aben KK, van der Marel SL, Ye Y, Wood CG, Pu X, Mazur AM, Boulygina ES, Chekanov NN, Foglio M, Lechner D, Gut I, Heath S, Blanche H, Hutchinson A, Thomas G, Wang Z, Yeager M, Fraumeni JF Jr, Skryabin KG, McKay JD, Rothman N, Chanock SJ, Lathrop M, Brennan P: Genome-wide association study of renal cell carcinoma identifies two susceptibility loci on 2p21 and 11q13.3. Nat Genet 2011, 43:60-65.

33. Melendez B, Rodriguez-Perales S, Martinez-Delgado B, Otero I, Robledo M, Martinez-Ramirez A, Ruiz-Llorente S, Urioste M, Cigudosa JC, Benitez J: Molecular study of a new family with hereditary renal cell carcinoma and a translocation t(3;8)(p13;q24.1). Hum Genet 2003, 112:178-185.

34. Drabkin HA, Gemmill RM: Obesity, cholesterol, and clear-cell renal cell carcinoma (RCC). Adv Cancer Res 2010, 107:39-56.

35. Poland KS, Azim M, Folsom M, Goldfarb R, Naeem R, Korch C, Drabkin HA, Gemmill RM, Plon SE: A constitutional balanced t(3;8)(p14;q24.1) translocation results in disruption of the TRC 8 gene and predisposition to clear cell renal cell carcinoma. Genes Chromosomes Cancer 2007. 46:805-812.

36. Linehan WM, Srinivasan $\mathrm{R}$, Schmidt LS: The genetic basis of kidney cancer: a metabolic disease. Nat Rev Urol 2010, 7:277-85.

37. Bennett KL, Mester J, Eng C: Germline epigenetic regulation of KILLIN in Cowden and Cowden-like syndrome. JAMA 2010, 304:2724-2732.

38. Stengel B: Chronic kidney disease and cancer: a troubling connection. $J$ Nephrol 2010, 23:253-262.

39. Maisonneuve P, Agodoa L, Gellert R, Stewart JH, Buccianti G, Lowenfels AB, Wolfe RA, Jones E, Disney AP, Briggs D, McCredie M, Boyle P: Cancer in patients on dialysis for end-stage renal disease: an international collaborative study. Lancet 1999, 354:93-99.

40. Adami J, Gabel H, Lindelof B, Ekstrom K, Rydh B, Blimelius B, Ekbom A, Adami HO, Granath F: Cancer risk following organ transplantation: a nationwide cohort study in Sweden. Br J Cancer 2003, 89:1221-1227.

41. Kasiske BL, Snyder JJ, Gilbertson DT, Wang C: Cancer after kidney transplantation in the United States. Am J Transplant 2004, 4:905-913.

42. Vajdic CM, McDonald SP, McCredie MR, van Leeuwen MT, Stewart JH, Law M, Chapman JR, Webster AC, Kaldor JM, Grulich AE: Cancer incidence before and after kidney transplantation. JAMA 2006, 296:2823-2831.

43. Villeneuve PJ, Schaubel DE, Fenton SS, Shepherd FA, Jiang Y, Mao Y Cancer incidence among Canadian kidney transplant recipients. Am J Transplant 2007, 7:941-948.

44. Stewart JH, Buccianti G, Agodoa L, Gellert R, McCredie MR, Lowenfels AB, Disney AP, Wolfe RA, Boyle P, Maisonneuve P: Cancers of the kidney and urinary tract in patients on dialysis for end-stage renal disease: analysis of data from the United States, Europe, and Australia and New Zealand. J Am Soc Nephrol 2003, 14:197-207.

45. Mandayam S, Shahinian VB: Are chronic dialysis patients at increased risk for cancer? J Nephrol 2008, 21:166-174.

46. Jorgensen $L$, Heuch I, Jenssen $T$, Jacobsen BK: Association of albuminuria and cancer incidence. J Am Soc Nephrol 2008, 19:992-998.

47. Martins D, Tareen N, Norris KC: The epidemiology of end-stage renal disease among African Americans. Am J Med Sci 2002, 323:65-71.

48. US Renal Data System, USRDS 2009 Annual Data Report: Atlas of end-stage renal disease in the United States. Bethesda, National Institutes of Health, National Institute of Diabetes and Digestive and Kidney Diseases; 2009 [http://www.usrds.org/atlas.htm].

49. Klein JB, Nguyen CT, Saffore L, Modlin CT III, Modlin CS Jr: Racial disparities in urologic health care. J Natl Med Assoc 2010, 102:108-117.

50. Clase CM, Garg AX, Kiberd BA: Prevalence of low glomerular filtration rate in nondiabetic Americans: Third National Health and Nutrition Examination Survey (NHANES III). J Am Soc Nephrol 2002, 13:1338-1349.

51. Coresh J, Astor BC, Greene T, Eknoyan G, Levey AS: Prevalence of chronic kidney disease and decreased kidney function in the adult US population: Third National Health and Nutrition Examination Survey. Am J Kidney Dis 2003, 41:1-12.

52. Centers for Disease Control and Prevention (CDC): Prevalence of chronic kidney disease and associated risk factors - United States, 1999-2004. MMWR Morb Mortal Wkly Rep 2007, 56:161-165.

53. McClellan WM, Newsome BB, McClure LA, Howard G, Volkova N, Audhya P, Warnock DG: Poverty and racial disparities in kidney disease: the REGARDS study. Am J Nephrol 2010, 32:38-46.

54. Walker WG, Neaton JD, Cutler JA, Neuwirth R, Cohen JD: Renal function change in hypertensive members of the Multiple Risk Factor Intervention Trial. Racial and treatment effects. The MRFIT Research Group. JAMA 1992, 268:3085-3091.

55. Hebert LA, Kusek JW, Greene T, Agodoa LY, Jones CA, Levey AS, Breyer JA, Faubert $P$, Rolin HA, Wang SR: Effects of blood pressure control on pregressive renal disease in blacks and whites. Modification of Diet in Renal Disease Study Group. Hypertension 1997, 30:428-435.

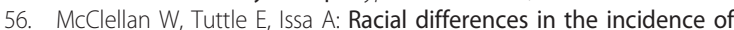
hypertensive end-stage renal disease (ESRD) are not entirely explained by differences in the prevalence of hypertension. Am J Kidney Dis 1988, 12:285-290.

57. Genovese G, Friedman DJ, Ross MD, Lecordier L, Uzureau P, Freedman BI, Bowden DW, Langefeld CD, Oleksyk TK, Knob AU, Bernhardy AJ, Hicks PJ, Nelson GW, Vanhollebeke B, Winkler CA, Kopp JB, Pays E, Pollak MR: Association of trypanolytic ApoL1 variants with kidney disease in African-Americans. Science 2010, 329:841-845.

58. Samanic C, Gridley G, Chow W-H, Lubin J, Hoover RN, Fraumeni JF Jr: Obesity and cancer risk among white and black United States veterans. Cancer Causes Control 2003, 15:35-43.

59. Samanic C, Chow WH, Gridley G, Jarvholm B, Fraumeni JF Jr: Relation of body mass index to cancer risk in 362,552 Swedish men. Cancer Causes Control 2006, 17:901-909.

60. Ildaphonse G, George PS, Mathew A: Obesity and kidney cancer risk in men - a meta-analysis (1992-2008). Asian Pacific J Cancer Prev 2009, 10:279-286.

61. Mathew A, George PS, Ildaphonse G: Obesity and kidney cancer risk in women - a meta-analysis (1992-2008). Asian Pacific J Cancer Prev 2009, 10:471-478.

62. Renehan AG, Tyson M, Egger M, Heller RF, Zwahlen M: Body mass index and incidence of cancer: a systematic review and meta-analysis of prospective observational studies. Lancet 2008, 371:569-578.

63. Flegal KM, Carroll MD, Ogden $\mathrm{CL}$, Johnson $\mathrm{CL}$ : Prevalence trends in obesity among US adults, 1999-2000. JAMA 2002, 288:1723-1727.

64. World Health Organization: Obesity: preventing and managing the global epidemic. Report of a $\mathrm{HO}$ consultation on obesity. WHO technical report series (no. 894) Geneva, Switzerland: World Health Organization; 2000.

65. Flegal KM, Carroll MD, Ogden CL, Curtin LR: Prevalence and trends in obesity among US adults, 1999-2008. JAMA 2010, 303:235-241.

66. Centers for Disease Control: Differences in prevalence of obesity among black, white, and Hispanic adults — United States, 2006-2008. MMWR: Morbidity and Mortality Weekly Report 2009, 58:740-4.

67. Cohen SS, Gammon MD, Signorello LB, North KE, Lange EM, Fowke JH, Hargreaves MK, Cai Q, Zheng W, Blot WJ, Matthews CE: Serum adiponectin 
in relation to body mass index and other correlates in black and white women. Ann Epidemiol 2010.

68. Hanley AJ, Bowden D, Wagenknecht LE, Balasubramanyam A, Langfeld C, Saad MF, Rotter Jl, Guo X, Chen YD, Bryer-Ash M, Norris JM, Haffner SM: Associations of adiponectin with body fat distribution and insulin sensitivity in nondiabetic Hispanics and African-Americans. J Clin Endocrinol Metab 2007, 92:2665-71.

69. Duncan BB, Schmidt MI, Pankow JS, Bang H, Couper D, Ballantyne CM, Hoogeveen RC, Heiss G: Adiponectin and the development of type 2 diabetes: the atherosclerosis risk in communities study. Diabetes 2004, 53:2473-8.

70. Steffes MW, Gross MD, Schreiner PJ, Yu X, Hilner JE, Gingerich R, Jacobs DR $J \mathrm{r}$ : Serum adiponectin in young adults-interactions with central adiposity, circulating levels of glucose, and insulin resistance: the CARDIA study. Ann Epidemiol 2004, 14:492-8.

71. Araneta MR, Barrett-Connor E: Adiponectin and ghrelin levels and body size in normoglycemic Filipino, African-American, and white women. Obesity 2007, 15:2454-62

72. Kanaya AM, Wassel Fyr C, Vittinghoff E, Havel PJ, Cesari M, Nicklas B, Harris T, Newman AB, Satterfield S, Cummings SR, Health ABC Study: Serum adiponectin and coronary heart disease risk in older Black and White Americans. J Clin Endocrinol Metab 2006, 91:5044-50.

73. Hulver MW, Saleh O, MacDonald KG, Pories WJ, Barakat HA: Ethnic differences in adiponectin levels. Metabolism 2004, 53:1-3.

74. Schutte AE, Huisman HW, Schutte R, Malan L, van Rooyen JM, Malan NT, Schwarz PE: Differences and similarities regarding adiponectin investigated in African and Caucasian women. Eur J Endocrinol 2007, 157:181-8.

75. Spyridopoulos TN, Petridou ET, Skalkidou A, Dessypris N, Chrousos GP, Mantzoros CS, Obesity and Cancer Oncology Group: Low adiponectin levels are associated with renal cell carcinoma: a case-control study. Int J Cancer 2007, 120:1573-1578.

76. Horiguchi A, Ito K, Sumitomo M, Kimura F, Asano T, Hayakawa M: Decreased serum adiponectin levels in patients with metastatic renal cell carcinoma. Jpn J Clin Oncol 2008, 38:106-111.

77. Pinthus JH, Kleinmann N, Tisdale B, Chatterjee S, Lu JP, Gillis A, Hamlet T, Singh G, Farrokhyar F, Kapoor A: Lower plasma adiponectin levels are associated with larger tumor size and metastasis in clear-cell carcinoma of the kidney. Eur Urol 2008, 54:866-873.

78. Calle EE, Kaaks R: Overweight, obesity and cancer: epidemiological evidence and proposed mechanisms. Nature Rev Cancer 2004, 4:579-591.

79. Kellerer M, von Eye CH, Muhlhofer A, Capp E, Mosthaf L, Bock S, Petrides PE, Haring HU: Insulin- and insulin-like growth-factor-I receptor tyrosinekinase activities in human renal carcinoma. Int J Cancer 1995, 62:501-507.

80. Fowke JH, Matthews $\mathrm{CE}$, Y U H, Cai Q, Cohen S, Buchowski MS, Zheng W Blot WJ: Racial differences in the association between body mass index (BMI) and serum IGF-1, IGF-2, and IGFBP-3. Endocrine-Related Cancer 2010, 17:51-60.

81. Gago-Dominguez M, Castelao JE, Yuan JM, Ross RK, Yu MC: Lipid peroxidation: a novel and unifying concept of the etiology of renal cell carcinoma (United States). Cancer Causes Control 2002, 13:287-293.

82. Flaherty KT, Fuchs CS, Colditz GA, Stampfer MA, Speizer FE, Willett WC, Curhan GC: A prospective study of body mass index, hypertension, and smoking and the risk of renal cell carcinoma (United States). Cancer Causes Control 2005, 16:1099-1106.

83. Yuan JM, Castelao JE, Gago-Dominguez M, Ross RK, Yu MC: Hypertension, obesity and their medications in relation to renal cell carcinoma. $\mathrm{Br} J$ Cancer 1998, 77:1508-1513.

84. McLaughlin JK, Chow WH, Mandel JS, Mellemgaard A, McCredie M, Lindblad P, Schlehofer B, Pommer W, Niwa S, Adami HO: International renal-cell cancer study. VIII. Role of diuretics, other anti-hypertensive medications and hypertension. Int J Cancer 1995, 63:216-221.

85. Shapiro JA, Williams MA, Weiss NS, Stergachis A, LaCroix AZ, Barlow WE: Hypertension, antihypertensive medication use, and risk of renal cell carcinoma. Am J Epidemiol 1999, 149:521-530.

86. Fryzek JP, Poulson AH, Johnsen SP, McLaughlin JK, Sorensen HT, Friis S: A cohort study of antihypertensive treatments and risk of renal cell cancer. Br J Cancer 2005, 92:1302-1306.

87. Weikert S, Boeing H, Pischon T, Weikert C, Olsen A, Tjonneland A, Overvad K, Becker N, Linseisen J, Trichopoulou A, Mountokalakis T, Trichopoulos D, Sieri S, Palli D, Vineis P, Panico S, Peeters PH, Bueno-de-
Mesquita HB, Verschuren WM, Ljungberg B, Hallmans G, Berglund G, González CA, Dorronsoro M, Barricarte A, Tormo MJ, Allen N, Roddam A, Bingham S, Khaw KT, Rinaldi S, Ferrari P, Norat T, Riboli E: Blood pressure and risk of renal cell carcinoma in the European Prospective Investigation into Cancer and Nutrition. Am J Epidemiol 2008, 167:438-446.

88. Choi MY, Jee SH, Sull JW, et al: The effect of hypertension on the risk for kidney cancer in Korean men. Kidney Int 2005, 67:647-652.

89. Benichou J, Chow WH, McLaughlin JK, Mandel JS, Fraumeni JF Jr: Population attributable risk of renal cell cancer in Minnesota. Am J Epidemiol 1998, 148:424-430.

90. Hertz RP, Unger AN, Cornell JA, Saunders E: Racial disparities in hypertension prevalence, awareness, and management. Arch Intern Med 2005, 165:2098-2014.

91. Egan BM, Zhao Y, Axon RN: US trends in prevalence, awareness, treatment, and control of hypertension, 1988-2008. JAMA 2010, 303:2043-2050

92. Klag MJ, Whelton PK, Randall BL, Neaton JD, Brancati FL, Stamler J: Endstage renal disease in African-American and white men: 16-year MRFIT findings. JAMA 1997, 277:1293-1298.

93. Rosenberg L, Stephenson WP, Rao RS, Palmer JR, Strom BL, Shapiro S: The diagnosis of renal cell cancer in relation to hypertension (United States). Cancer Causes Control 1998, 9:611-614.

94. Jones DW: What is the role of obesity in hypertension and target organ injury in African Americans? Am J Med Sci 1999, 317:147-151.

95. Vineis $P$, Alavanja M, Buffler P, Fontham E, Franceschki S, Gao YT, Gupta PC, Hackshaw A, Matos E, Samet J, Sitas F, Smith J, Stayner L, Straif K, Thun M, Wichmann HE, Wu AH, Zaridze D, Peto R, Doll R: Tobacco and cancer: recent epidemiological evidence. J Natl Cancer Inst 2004, 96:99-106.

96. Hunt JD, van der Hel OL, McMillan GP, Boffetta P, Brennan P: Renal cell carcinoma in relation to cigarette smoking: meta-analysis of 24 studies. Int J Cancer 2005, 114:101-108.

97. Yuan JM, Castelao JE, Gago-Dominguez M, Yu MC, Ross RK: Tobacco use in relation to renal cell carcinoma. Cancer Epidemiol Biomarkers Prev 1998, 5:429-433

98. McLaughlin JK, Lindblad P, Mellemgaard A, McCredie M, Mandel JS, Schlehofer B, Pommer W, Adami HO: International renal-cell cancer study. I. Tobacco use. Int J Cancer 1995, 60:194-198.

99. US Department of Health and Human Services: Tobacco use among US Racial/Ethnic minority groups: A report of the Surgeon General. Atlanta, GA: US Department of Health and Human Services, Centers for Disease Control and Prevention, National Center for Chronic Disease Prevention and Health Promotion, Office on Smoking and Health; 1998.

100. Yood MU, McCarthy BD, Kucera KJ, Wells K, Oliveria S, Stang P: Racial differences in reaching target low-density lipoprotein goal among individuals treated with prescription statin therapy. Am Heart J 2006, 152:777-784.

101. Meadows TA, Bhatt DL, Hirsch AT, Creager MA, Califf RM, Ohman EM, Cannon CP, Eagle Ka, Alberts MJ, Goto S, Smith SC Jr, Wilson PW, Watson KE, Steg PG, REACH Registry Investigators: Ethnic differences in the prevalence and treatment of cardiovascular risk factors in US outpatients with peripheral arterial disease: insights from the reduction of atherothrombosis for continued health (REACH) registry. Am Heart J 2009, 158:1038-1045.

102. Lipworth $L$, Tarone RE, McLaughlin JK: The epidemiology of renal cell carcinoma. J Urol 2006, 176:2353-2358.

103. Lipworth L, Tarone RE, Lund L, McLaughlin JK: Epidemiologic characteristics and risk factors for renal cell cancer. Clin Epidemiol 2009, 1:33-43.

104. Weikert S, Boeing H, Pischon T, Olsen A, Tjonneland A, Overvad K, Becker N, Linseisen J, Lahmann PH, Arvaniti A, Kassapa C, Trichoupoulou A, Sieri S, Palli $D$, Tumino $R$, Vineis $P$, Panico $S$, van Gils $C H$, Peeters PH, Bueno-deMesquita $H B$, Büchner $F L$, Ljungberg B, Hallmans $G$, Berglund $G$, Wirfält $E$, Pera G, Dorronsoro M, Gurrea AB, Navarro C, Martinez C, Quirós JR, Allen N, Roddam A, Bingham S, Jenab M, Slimani N, Norat T, Riboli E: Fruits and vegetables and renal cell carcinoma: findings from the European Prospective Investigation into Cancer and Nutrition (EPIC). Int J Cancer 2006, 118:3133-3139.

105. van Dijk BAC, Schouten LJ, Kiemeney LALM, Goldbohm A, van den Brandt PA: Vegetable and fruit consumption and risk of renal cell carcinoma: results form the Netherlands cohort study. Int I Cancer 2005, 117:648-654. 
106. Wolk A, Gridley G, Niwa S, Lindblad P, McCredie M, Mellemgaard A, Mandel JS, Wahrendorf J, McLaughlin JK, Adami HO: International renalcell cancer study. VII. Role of diet. Int J Cancer 1996, 65:67-73.

107. Lee JE, Spiegelman D, Hunter DJ, Albanes D, Bernstein L, van den Brandt PA, Buring JE, Cho E, English DR, Freudenheim JL, Giles GG, Graham S, Horn-Ross PL, Håkansson N, Leitzmann MF, Männistö S, McCullough ML, Miller AB, Parker AS, Rohan TE, Schatzkin A, Schouten LJ, Sweeney C, Willett WC, Wolk A, Zhang SM, Smith-Warner SA: Fat, protein, and meat consumption and renal cell cancer risk: a pooled analysis of 13 prospective studies. J Natl Cancer Inst 2008, 100:1695-1706.

108. Lee JE, Hunter DJ, Spiegelman D, Adami HO, Albanes D, Bernstein L, van den Brandt PA, Buring JE, Cho E, Folsom AR, Freudenheim JL, Giovannucci E, Graham S, Horn-Ross PL, Leitzmann MF, McCullough ML, Miller AB, Parker AS, Rodriguez C, Rohan TE, Schatzkin A, Schouten LJ, Virtanen M, Willett WC, Wolk A, Zhang SM, Smith-Warner SA: Alcohol intake and renal cell cancer in a pooled analysis of 12 prospective studies. J Natl Cancer Inst 2007, 99:801-810.

109. Bagnardi V, Blangiardo M, La Vecchia C, Corrao G: A meta-analysis of alcohol drinking and cancer risk. Br J Cancer 2001, 85:1700-1705.

110. Lindblad P, Mellemgaard A, Schlehofer B, Adami HO, McCredie M, McLaughlin JK, Mandel JS: International renal-cell cancer study. V. Reproductive factors, gynecologic operations and exogenous hormones. Int J Cancer 1995, 61:192-198.

111. Kabat GC, Navarro Silvera SA, Miller AB, Rohan TE: A cohort study of reproductive and hormonal factors and renal cell cancer risk in women. Br J Cancer 2007, 96:845-849.

112. Zucchetto A, Talamini R, Dal Maso L, Negri E, Polesel J, Ramazzotti V, Montella M, Canzonieri V, Serraino D, La Vecchia C, Franceschi S: Reproductive, menstrual, and other hormone-related factors and risk of renal cell cancer. Int J Cancer 2008, 123:2213-2216.

113. Setiawan W, Kolonel LN, Henderson BE: Menstrual and reproductive factors and risk of renal cell cancer in the multiethnic cohort. Cancer Epidemiol Biomarkers Prev 2009, 18:337-340.

114. Lambe M, Lindblad P, Wuu J, Remler R, Hsieh CC: Pregnancy and risk of renal cell cancer: a population-based study in Sweden. Br J Cancer 2002, 86:1425-1429.

115. Sali D, Boffetta P: Kidney cancer and occupational exposure to asbestos: a meta-analysis of occupational cohort studies. Cancer Causes Control 2000, 11:37-47

116. McLaughlin JK: Renal cell cancer and exposure to gasoline: a review. Environ Health Perspect Supp/ 1993, 101(suppl 6):111-114

117. International Agency for Research on Cancer: Occupational exposures in petroleum refining; crude oil and major petroleum fuels. IARC Monogr Eval Carcinog Risks Hum 1989, 45:39-117.

118. Henschler D, Vamvakas S, Lammert M, Dekant W, Kraus B, Thomas B, Ulm K: Increased incidence of renal cell tumors in a cohort of cardboard workers exposed to trichloroethylene. Arch Toxicol 1995, 69:291-299.

119. Vamvakas S, Bruning T, Thomasson B, Lammett M, Baumuller A, Bolt HM, Dekant W, Birner G, Henschler D, Ulm K: Renal cell cancer correlated with occupational exposure to trichloroethene. J Cancer Res Clin Oncol 1998, 124:374-382.

120. Bruning T, Pesch B, Wiesenhutter B, Rabstein S, Lammert M, Baumuller A, Bolt HM: Renal cell cancer risk and occupational exposure to trichloroethylene: results of a consecutive case-control study in Arnsberg, Germany. Am J Ind Med 2003, 43:274-285.

121. McLaughlin JK, Blot WJ: A critical review of epidemiology studies of trichloroethylene and perchloroethylene and risk of renal cell cancer. Int Arch Occup Environ Health 1997, 70:222-231.

122. Green LC, Lash TL: Re: "Renal cell cancer correlated with occupational exposure to trichloroethylene". J Cancer Res Clin Oncol 1999, 125:430-432

123. Cherrie JW, Kromhout H, Semple S: The importance of reliable exposure estimates in deciding whether trichloroethylene can cause kidney cancer. J Cancer Res Clin Oncol 2001, 127:400-404.

124. Blair A, Hartge P, Stewart PA, McAdams M, Lubin J: Mortality and cancer incidence of aircraft maintenance workers exposed to trichloroethylene and other organic solvents and chemicals: extended follow up. Occup Environ Med 1998, 55:161-171.

125. Boice JD, Marano DE, Fryzek JP, Sadler CJ, McLaughlin JK: Mortality among aircraft manufacturing workers. Occup Environ Med 1999, 56:581-597.

126. Raaschou-Nielsen O, Hansen J, McLaughlin JK, Kolstad H, Christensen JM, Tarone RE, Olsen JH: Cancer risk among workers at Danish companies using trichloroethylene: a cohort study. Am J Epidemiol 2003, 158:1182-1192.

127. Wong O: Carcinogenicity of trichloroethylene: an epidemiologic assessment. Clin Occup Environ Med 2004, 4:557-589.

Pre-publication history

The pre-publication history for this paper can be accessed here: http://www.biomedcentral.com/1471-2407/11/133/prepub

doi:10.1186/1471-2407-11-133

Cite this article as: Lipworth et al:: Renal cell cancer among African Americans: an epidemiologic review. BMC Cancer 2011 11:133.

\section{Submit your next manuscript to BioMed Central and take full advantage of:}

- Convenient online submission

- Thorough peer review

- No space constraints or color figure charges

- Immediate publication on acceptance

- Inclusion in PubMed, CAS, Scopus and Google Scholar

- Research which is freely available for redistribution

Submit your manuscript at www.biomedcentral.com/submit
Biomed Central 